\title{
VARIABILITY OF SHELL IN GASTROPODS OF THE GENUS BORYSTHENIA LINDHOLM, 1914: TESTING THE STATISTICAL APPROACH IN SEARCH OF TRAITS FOR THE RECENT AND FOSSIL SPECIES DELIMITATION
}

\section{MIНАИВІСТЬ ЧЕРЕПАШКИ ЧЕРЕВОНОГИХ МОЛЮСКІВ РОАУ ВОRYSTHENIA LINDHOLM, 1914: ТЕСТУВАННЯ СТАТИСТИЧНОГО ПІАХОАУ В ПОШУКАХ ОЗНАК АИЯ РОЗМЕЖУВАННЯ СУЧАСНИХ ТА ВИКОПНИХ ВИАІВ}

\author{
Diana S. Osipova ${ }^{1,2}$, Olga Yu. Anistratenko ${ }^{2,3}$, Vitaliy V. Anistratenko ${ }^{2}$ \\ А. С. Осіпова ${ }^{1,2}$, О. Ю. Аністратенко ${ }^{2,3}$, В. В. Аністратенко ${ }^{2}$ \\ ${ }^{1}$ National University of “Kyiv-Mohyla Academy”, 2 G. Skovoroda Str., Kyiv, Ukraine 04070 \\ (diana.osipova@izan.kiev.ua) \\ I. I. Schmalhausen Institute of Zoology of the NAS of Ukraine, 15 B. Khmelnitsky St., Kyiv, Ukraine 01030, \\ (anistrat@izan.kiev.ua) \\ ${ }^{3}$ Institute of Geological Sciences, NAS of Ukraine, 55-b O. Honchara Str., Kyiv, Ukraine, 01601 \\ (olga.anistrat@gmail.com)
}

\begin{abstract}
The gastropod mollusc genus Borysthenia Lindholm, 1914 comprises many species throughout Europe, Asia, North Africa and North America but species delimitation, based mainly on shell morphology (only possible concerning the fossil records) is often disputable. Statistical methods used to test if the shell measurements are reliable traits in delimitation of recent and fossil species in gastropod molluscs of the genus Borysthenia. Our analyses based on quantitative study of over 100 specimens of the Borysthenia species both modern and fossil. It is concluded that the dimensional characteristics of their shell are suitable for the differentiation of both recent and fossil (at least of Pontian age) species through the statistical processing of quantitative data. Through the morphological study of type material, taxonomic status of B. jalpuchense Gozhik, 2002 and B. vinogradovkaense Gozhik, 2002 described from the middle-pontian deposits of Ukraine revised. It is suggested that these taxa are considered two distinct though close relative extinct species. Stratigraphic range of $B$. jalpuchense is expanded up to the Lower Pontian. All the modern individuals of Borysthenia involved are attributed to B. menkeana (Jelski, 1863) due to their exact correspondence to the lectotype of this species.

Keywords: Valvatidae, Borysthenia, fossil and modern species, shell morphology, taxonomy, south Ukraine
\end{abstract}

\begin{abstract}
РіА черевоногих молюсків Borysthenia Lindholm, 1914 включає багато видів з усієї Європи, Азії, Північної Африки та Північної Америки, але визначення границь виАів, що базується, головним чином, на морфології черепашки (єАине можливе Аля викопних знахідок), часто є Аискусійним. Нами використано статистичні методи обробки промірів черепашки гастропоА poдy Borysthenia Аля перевірки, чи є параметри черепашки наАійною ознакою розмежування сучасних та викопних виАів. Наш аналіз побудований на кількісному вивченні понад 100 екземплярів Borysthenia, як сучасних, так і викопних. Зроблено висновок про те, що розмірні характеристики черепашки є приАатними А^я Аиференціації як сучасних, так і викопних (принаймні, понтичного віку) видів шляхом статистичної обробки кількісних даних. Вивчення типового матеріалу дозволило уточнити таксономічний статус B. jalpuchense Gozhik, 2002 та B. vinogradovkaense Gozhik, 2002, що були описані з сереАньопонтичних відкладів України. Запропоновано вважати ці таксони Авома окремими, хоча й близько спорідненими вимерлими видами. Стратиграфічний діапазон B. jalpuchense розширено Ао нижнього понту. Все сучасні особини Borysthenia віАнесено Ао B. menkeana (Jelski, 1863), оскільки вони точно відповідають мектотипові цього виду.

Ключові слова: Valvatidae, Borysthenia, викопні та сучасні виАи, морфологія черепашки, таксономія, південна Україна.
\end{abstract}

\section{INTRODUCTION}

The gastropod mollusc family Valvatidae Gray, 1840 represents a small group of freshwater snails known from Jurassic. It is distributed throughout the Europe, the North part and the mountainous parts of Asia, North Africa and North America (Starobogatov, 1970). Being ovoviviparous and possessing very slender (vs. broad) marginal

Цитування: Осіпова А.С., Аністратенко О.Ю., Аністратенко В.В. Мінливість черепашки черевоногих молюсків роду Воrysthenia Lindholm, 1914: тестування статистичного піАходу в пошуках ознак Аля розмежування сучасних та викопних виАів. Збірник наукових праць Інституту геологічних наук НАН України. 2021. Том 14, вип. 1. С. 110-116. https://doi. org/10.30836/igs.2522-9753.2021.227603.

Citation: Osipova D.S., Anistratenko O. Yu, Anistratenko V.V., 2021. Variability of shell in gastropods of the genus Borysthenia Lindholm, 1914: testing the statistical approach in search of traits for the recent and fossil species delimitation. Collection of scientific works of the Institute of Geological Sciences NAS of Ukraine. Vol. 14, iss. 1. Pp. 110-116. https://doi.org/10.30836/ igs.2522-9753.2021.227603. 
radular teeth the valvatid genus Borysthenia Lindholm, 1914 (type species Valvata jelskii Crosse, 1863) makes a clearly distinct branch within the family having a rank of subfamily Borystheniinae Starobogatov in Sitnikova, 1983 (Sitnikova, 1983). The rest of valvatid species are egg-lying molluscs.

Modern distribution of Borysthenia is limited to the waters of South Baltic, Danube, Dniester and Dnieper river basins (Sitnikova et al., 1986; Glöer, 2002, 2019; Welter-Schultes, 2012). In fresh waters of the Ukraine the genus is represented by four nominal species: $B$. naticina (Menke, 1846), $B$. menkeana (Jelski, 1863), B. naticina var. alligans (Lindholm, 1927), and B. jelskii (Crosse, 1863) (Sitnikova et al., 1986; Anistratenko, Anistratenko, 2001; Anistratenko et al., 2010). However, many authors consider these taxa as a same species (Falkner et al., 2001; Vinarski, Kantor, 2016).
Fossil representatives of the genus were more widely distributed and occurred in the Miocene deposits of Europe and Kazakhstan (Starobogatov, 1970; Gozhik, 2002; Gozhik, Datsenko, 2007; Anistratenko et al., 2010; Haszprunar, 2014). This also concerns to Ukraine: for instance, two new species of Borysthenia were described by Peter Gozhik (Gozhik, 2002; Gozhik, Datsenko, 2007) from the Pontian deposits of South Ukraine and Moldova, namely B. jalpuchense Gozhik, 2002 and B. vinogradovkaense Gozhik, 2002.

The protoconch traits of the valvatid snails are well known (e.g. Anistratenko et al., 2010; Hawe et al., 2013), however teleoconch variability of both recent and fossil Borysthenia is not well studied. This makes it nearly impossible to assess accurately the conchological features in the taxonomy of the group for reliable differentiation of species (Osipova, Anistratenko, 2018; Osipova et al., 2019).

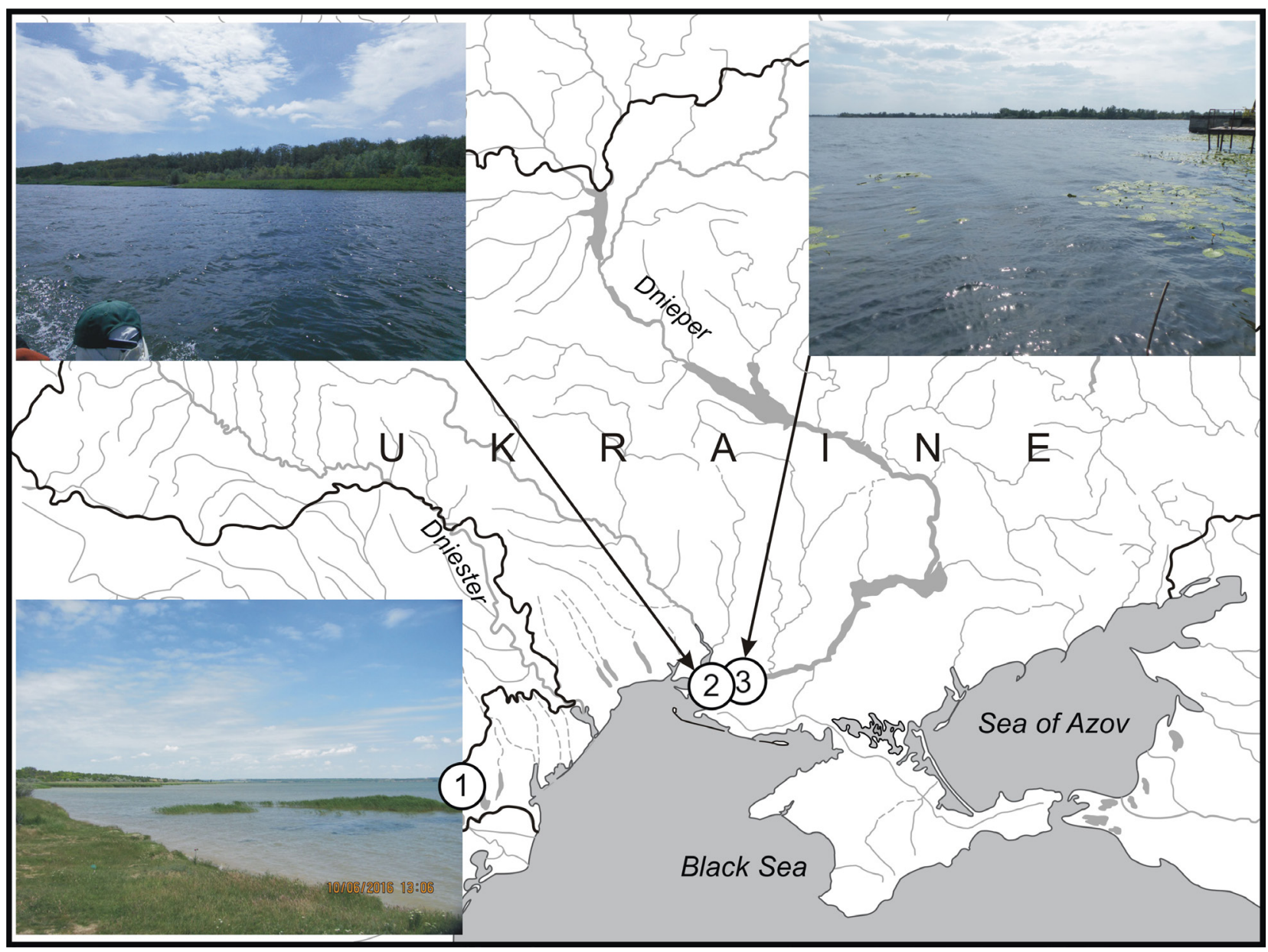

Fig. 1. The geographic positions and views of the localities of material studied. Details for each sampling point are given in Table 1.

Рис. 1. Географічне положення та вигляд місць збору вивченого матеріалу. Аеталі щодо кожної з точок збору надано у Таблиці 1. 
Table 1. List of the examined material

The numbers of localities refer to the text and figures

Таблиця 1. Перелік досліАженого матеріалу

Номери локалітетів відповідають таким у тексті та рисунках

\begin{tabular}{|l|l|l|l|l|l|l|l|}
\hline No & $\begin{array}{l}\text { Lot\# } \\
\text { IZAN }\end{array}$ & Locality & Date & $\mathrm{N}$ & $\mathrm{E}$ & Collect by \\
\hline 1 & 479 & $\begin{array}{l}\text { Yalpug Lake, Vinogradovka village, } \\
\text { Bolgrad district, Odessa region, } \\
\mathrm{N}_{1} \mathrm{P}_{1}\end{array}$ & 06.1987 & $45^{\circ} 39^{\prime} 29^{\prime \prime}$ & $28^{\circ} 35^{\prime} 08^{\prime \prime}$ & V. V. Anistratenko & 40 \\
\hline 2 & 478 & $\begin{array}{l}\text { Dnieper-Bug liman, near Rybalche } \\
\text { settlement, Kherson region }\end{array}$ & 1987 & $4^{\circ} 29^{\prime} 03^{\prime \prime}$ & $32^{\circ} 14^{\prime} 04^{\prime \prime}$ & not stated & 39 \\
\hline 3 & 390 & $\begin{array}{l}\text { Knieper River in Kherson City near } \\
\text { Kherson Hydrobiological station } \\
\text { of NAN Ukraine, depth 1,5-7,5 m }\end{array}$ & 18.05 .2016 & $46^{\circ} 35^{\prime} 55^{\prime \prime}$ & $32^{\circ} 34^{\prime} 51^{\prime \prime}$ & V. V. Anistratenko & 26 \\
\hline & \begin{tabular}{l} 
Total \\
\hline
\end{tabular} & & & 105 \\
\hline
\end{tabular}

The present study aims to define the ranges of variability in features of the shell measurements in molluscs of the genus Borysthenia and to assess reliability of these features in delimitation of recent and fossil species.

\section{MATERIAL AND METHODS}

Recent samples of Borysthenia were collected in the Dnieper-Bug estuary. Molluscs were hand-picked from aquatic vegetation and using a hydrobiological net or Petersen dragger at depths of 0.5-7.5 m. The fossil specimens came from the Lower Pontian deposits of the Lake Yalpuh near Vinogradovka village, Odessa region, Ukraine (age is determined by V.A. Prisyazhnyuk) (Fig. 1).

Altogether 105 specimens were studied and measured (Table 1). Apart from these the holotypes of two Borysthenia species were also studied: $B$. jalpuchense Gozhik, 2002 and B. vinogradovkaense Gozhik, 2002 described from the Middle Pontian $\left(\mathrm{N}_{1} \mathrm{P}_{2}\right)$ near Vinogradovka village (ind.\#3162 and \#3163 accordingly, after Gozhik, 2002). Images of the specimens were taken with a Leica M165C stereomicroscope equipped with digital camera. Before photographing shells were cleaned by ultrasound in a water bath. Measurements (Fig. 2) were made using MBS-9 stereoscopic microscope with an ocular-micrometer of $0,1 \mathrm{~mm}$ precision.

\section{RESULTS AND DISCUSSION}

It was found that the shell growth geometry (detected through the shell shape comparison) of recent and fossil Borysthenia are significantly different (Wilk's lambda: 0,5385, F=5,864 with significance level $p=0,01$ ). The difference is mainly expressed in relative height of shell spire but with the same whorls number (Fig. 3). Besides, the whorls of spire in fossil shells are less inflated, separated with shallower suture and therefore an outline of entirely shell looks more trochoid in comparison to recent ones.

In fact the studied samples have statistically different main shell indexes (ratio HSh/WSh and HSh/WA), although a significant overlap in some of their shell measurements also exists (Fig. 4).

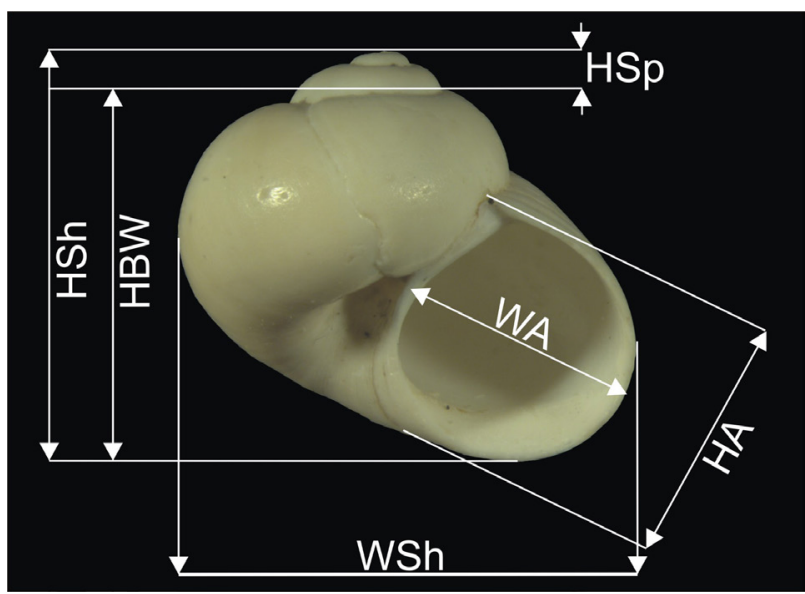

Fig. 2. Measuring of the shell parameters:

HSh - height of shell, HBW - height of body whorl, WSh - width of shell, HSp - height of spire, HA - height of aperture, WA - width of aperture.

Рис. 2. Виміри параметрів черепашки: HSh - висота черепашки, HBW - висота останнього звою, WSh - ширина черепашки, HSp - висота завитка, НА - висота устя, WA - ширина устя. 


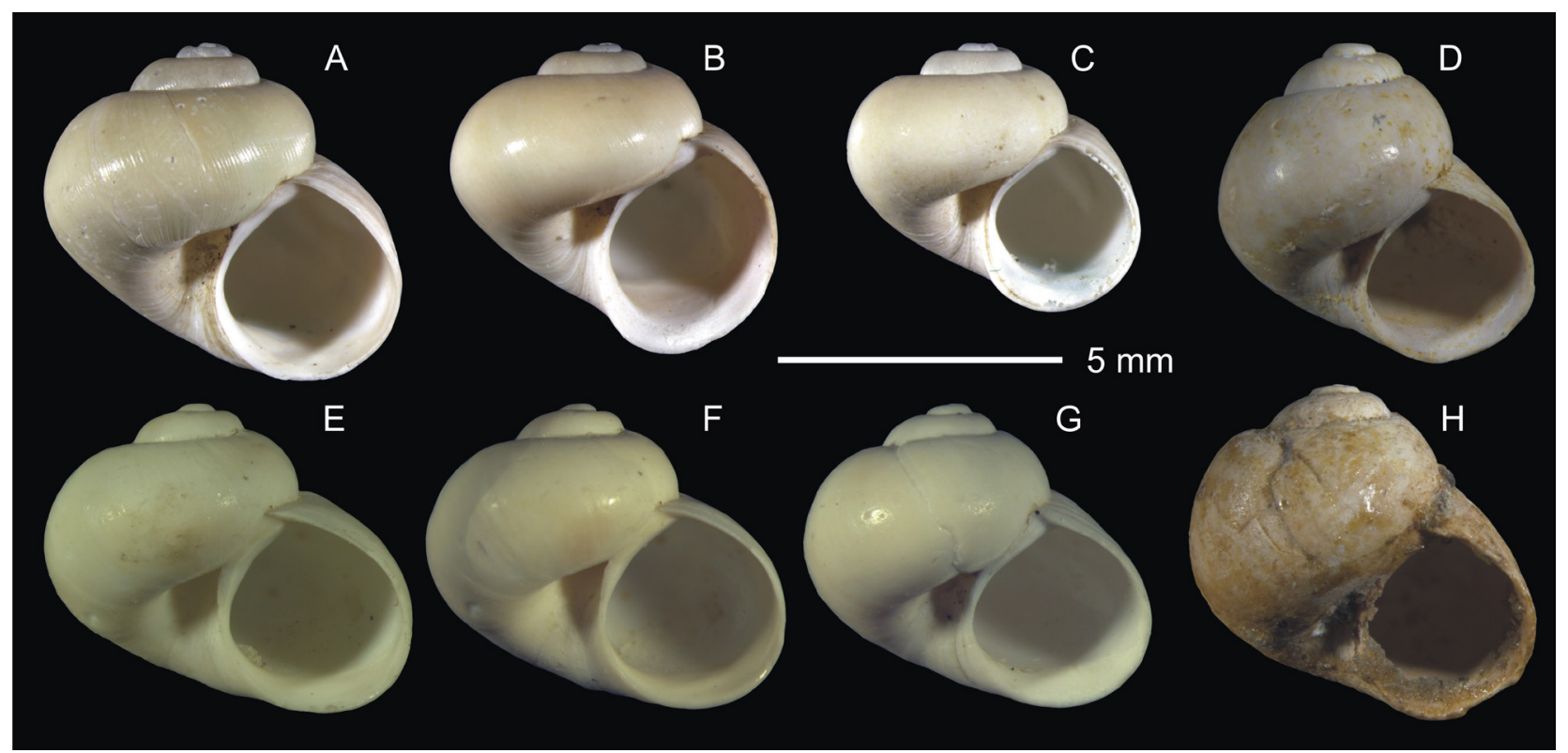

Fig. 3. Shells of examined Borysthenia species:

A-C - B. menkeana (Jelski, 1863) (locality 2 and 3); D - B. vinogradovkaense Gozhik, 2002 (holotype, $N_{1} P_{2}$ ); E-G-B. jalpuchense Gozhik, 2002 (locality 1, $\mathrm{N}_{1} \mathrm{P}_{1}$ ); H-B. jalpuchense Gozhik, 2002 (holotype, $\mathrm{N}_{1} \mathrm{P}_{2}$ ).

Рис. 3. Черепашки вивчених видів Borysthenia:

A-C-B. menkeana (Jelski, 1863) (місцезнаходження 2 та 3); D - B. vinogradovkaense Gozhik, 2002 (голотип, $\mathrm{N}_{1} \mathrm{P}_{2}$ ); E-G - B. jalpuchense Gozhik, 2002 (місцезнаходження 1, $\mathrm{N}_{1} \mathrm{P}_{1}$ ); H - B. jalpuchense Gozhik, 2002 (голотип, $\left.\mathrm{N}_{1} \mathrm{P}_{2}\right)$.

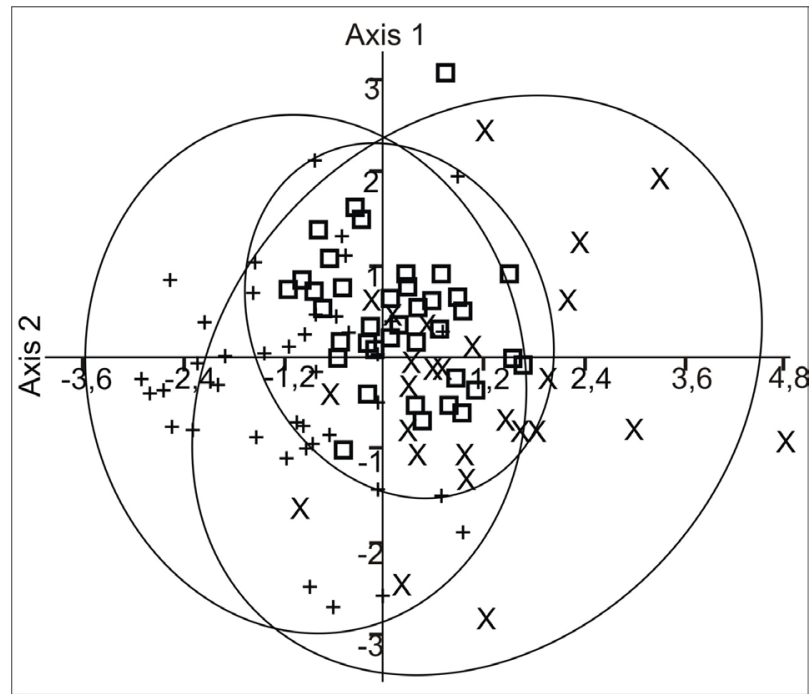

Fig. 4. Graphic distribution for shell measurements from 105 specimens of Borysthenia: ' $X$ ' - B. menkeana (locality 3); ‘ $\square$ ' - B. menkeana (locality 2); ‘+' - Early Pontian B. jalpuchense (locality $1, \mathrm{~N}_{1} \mathrm{P}_{1}$ ).

Рис. 4. Графічний розподіл промірів черепашки 105 зразків Borysthenia: ' $X$ ' - B. menkeana (locality 3); ‘ $\square$ - B. menkeana (locality 2); ‘+' - Early Pontian B. jalpuchense (locality $1, \mathrm{~N}_{1} \mathrm{P}_{1}$ ).
We consider the differences observed as sufficient to refer to the fossil (locality 1) and recent specimens of Borysthenia (localities 2, 3) as the two morphologically distinct species.

Since the holotype of B. jalpuchense (Fig. 3, $\mathrm{H})$ matches well to the main shell features of the specimens from the Lower Pontian deposits (sample \# 479) (Fig. 3, E-G) they may be considered conspecific. Thus, the stratigraphic range of $B$. jalpuchense in the Miocene was significantly expanded up to the Lower Pontian deposits.

Differences between the shell morphology of $B$. jalpuchense and $B$. vinogradovkaense (still known only by type series from the Middle Pontian) allow us to consider them as two distinct taxa on the species or the subspecies level (Fig. 3, D). The holotypes of $B$. jalpuchense and $B$. vinogradovkaense are slightly differentiating from each other. Shell whorls in $B$. vinogradovkaense comparatively inflated, increase regularly while in $B$. jalpuchense the whorls are flattened and increasing faster make more slender shell. Studied specimens from the Lower Pontian are characterizing with less inflated whorls, shallower suture and relatively shorter spire. All the specimens of Borysthenia came from the Lower 
Pontian deposits represent a highly monomorphic sample with a narrow range of individual variability.

The studied modern mollusc individuals of Borysthenia (Fig. 3, A-C) we attribute to $B$. menkeana due to their exact correspondence to the lectotype of this species, illustrated by Sitnikova et al. (1986). The overall similarity of $B$. menkeana and $B$. jalpuchense (Fig. 4) suggests that both species are closely related; given the age, $B$. jalpuchense might be a phylogenetic predecessor of $B$. menkeana.

Based on the obtained data we suggest that the representative taxa of the Pontian and recent Borysthenia should be interpreted as distinct but morphologically similar (and most likely related) species or varieties of one polymorphic species. Observed conchological differences can be explained by the influence of environmental conditions.

\section{CONCLUSION}

Analysis of the data obtained confirms that the dimensional characteristics of the Borysthenia shell are suitable for the differentiation of both recent and fossil (at least of Pontian age) species through the statistical processing of quantitative data. Morphological study of the type specimens (holotypes) of $B$. jalpuchense and $B$. vinogradovkaense supports their taxonomic status as two distinct though close relative extinct species. Stratigraphic distribution of $B$. jalpuchense apparently covers the lower- and middle-pontian deposits. All modern shells of Borysthenia involved in this study are attributed to $B$. menkeana since their shell morphology fairly corresponds to the lectotype of this species.

\section{Acknowledgements}

We dedicate this article to the memory of our late colleague, Academician Peter F. Gozhik, Director of the Institute of Geological Sciences NAS of Ukraine. Prof. P. F. Gozhik provided the type material of Borysthenia jalpuchense and $B$. vinogradovkaense. Dr. Igor I. Dzeverin (Institute of Zoology NAS of Ukraine) kindly helped us with statistical calculations. The shell images were taken at the User Facilities Center of the Institute of Zoology NAS of Ukraine.

\section{REFERENCES}

Anistratenko O., Degtyarenko E., Anistratenko V., 2010. Shell and radula comparative morphology of the Gastropod Molluscs family Valvatidae from the North Black Sea coast. Ruthenica, 20 (2). Pp. 91-101. https://ruthenica.net/node/1202 (In Russian).

Anistratenko V. V., Anistratenko O. Yu., 2001. Mollusca. Fasc. 1. B. 1: Class Polyplacophora or Chitons, Class Gastropoda Cyclobranchia, Scutibranchia and Pectinibranchia (part). Fauna of Ukraine. Vol. 29. Kiev: Veles. 240 p. (In Russian).

Falkner G., Bank R. A., von Proschwitz T., 2001. Check-list of the non-marine Molluscan Species-group taxa of the States of Northern, Atlantic and Central Europe (CLECOM I). Heldia (Munchner Malakologische Mitteilungen), 4 (1/2). Pp. 1-76.

Glöer P., 2002. Die Tierwelt Deutschlands. Teil 73: Die Süßwassergastropoden Nord- und Mitteleuropas. Bestimmungsschlüssel, Lebensweise, Verbreitung. Hackenheim: ConchBooks, 327 p.

Glöer P., 2019. The Freshwater Gastropods of the WestPalaearctis. Identification key, Anatomy, Ecology, Distribution. Volume 1. Neritidae, Hydrocenidae, Ampullariidae, Viviparidae, Thiaridae, Potamididae, Melanopsidae, Bithyniidae, Cochliopidae, Tateidae, Hydrobiidae, Lithoglyphidae, Bythinellidae, Emmericiidae, Truncatellidae, Assiminiidae, Valvatidae, Lymnaeidae, Physidae, Planorbidae, Acroloxidae, Ellobiidae, Otinidae. Hetlingen: Biodiversity Research Lab. $399 \mathrm{p}$.
Анистратенко О., Аегяренко Е., Анистратенко В. Сравнительная морфология раковины и радулы брюхоногих мол^юсков семейства Valvatidae из Северного Причерноморья. Ruthenica, 2010, 20 (2). C. 91-101. https://ruthenica.net/ node/1202

Анистратенко В.В., Анистратенко О. Ю. Момююски. Вып. 1. Kн. 1: Класс Панцирные или Хитоны, класс Брюхоногие Cyclobranchia, Scutibranchia и Pectinibranchia (часть). Фауна Украины. Том 29. Киев: Велес, 2001. 240 с.

Falkner G., Bank R. A., von Proschwitz T. Check-list of the nonmarine Molluscan Species-group taxa of the States of Northern, Atlantic and Central Europe (CLECOM I). Heldia (Munchner Malakologische Mitteilungen), 4 (1/2), 2001. Pp. 1-76.

Glöer P. Die Tierwelt Deutschlands. Teil 73: Die Süßwassergastropoden Nord- und Mitteleuropas. Bestimmungsschlüssel, Lebensweise, Verbreitung. Hackenheim: ConchBooks, 2002. 327 p.

Glöer P. The Freshwater Gastropods of the West-Palaearctis. Identification key, Anatomy, Ecology, Distribution. Vol. 1. Neritidae, Hydrocenidae, Ampullariidae, Viviparidae, Thiaridae, Potamididae, Melanopsidae, Bithyniidae, Cochliopidae, Tateidae, Hydrobiidae, Lithoglyphidae, Bythinellidae, Emmericiidae, Truncatellidae, Assiminiidae, Valvatidae, Lymnaeidae, Physidae, Planorbidae, Acroloxidae, Ellobiidae, Otinidae. Hetlingen: Biodiversity Research Lab., 2019. 399 p. 
Gozhik P. F., 2002. The Pontian freshwater mollusks of the Southern Ukraine and Moldova. Kyiv. 96 p. (In Ukrainian).

Gozhik P. F., Datsenko L. N., 2007. Fresh-water mollusks from the late Caenozoic in the south of the Eastern Europe. Part 2. Families Sphaeriidae, Pisidiidae, Corbiculidae, Neritidae, Viviparidae, Valvatidae, Bithyniidae, Lithoglyphidae, Melanopsidae. Kiev: Logos. 256 p. (In Russian).

Hasprunar G., 2014. A nomenclator of extant and fossil taxa of the Valvatidae (Gastropoda, Ectobranchia). ZooKeys, 377. Pp. 1-172. https://doi.org/10.3897/zookeys.377.6032

Hawe A., Heß M., Haszprunar G., 2013. 3D reconstruction of the anatomy of the ovoviviparous (?) freshwater gastropod Borysthenia naticina (Menke, 1845) (Ectobranchia: Valvatidae). Journal of Molluscan Studies, 79 (3). Pp. 191-204. https:// doi.org/10.1093/mollus/eyt018

Osipova D.S., Anistratenko V.V., 2018. Statistical study of the shell variability in molluscs of the genus Borysthenia (Gastropoda: Valvatidae). Abstract book of the Conference of young zoologists -2018 (Kiev, Institute of zoology, November 14-15, 2018). Kiev, 2018. P. 16. (Zoological courier, № 12.) http://mail.izan.kiev.ua/rmd/KMDZ18-abstr.pdf (In Russian).

Osipova D.S., Anistratenko V. V., 2019. Variability of valvatid gastropods of the genus Borysthenia Lindholm, 1914 and using the shell features for species delimitation: testing the statistical approach. Paleontological investigation of Don-Dnieper downwarp: materials of International scientific conference and XXXIX session of the Paleontological Society NAS of Ukraine (Hradyz'k, May 14-16, 2019). Kyiv. P. 88-89. (In Russian).

Sitnikova T. Ya., 1983. System of Baikal endemic species of the genus Megalovalvata and some problems of taxonomy of the family Valvatidae (Gastropoda, Pectinibranchia). Zoologicheskij zhurnal, 62. Pp. 32-43. (In Russian).

Sitnikova T. Ya., Starobogatov Ya. I., Chernogorenko E. V., 1986. The genus Borysthenia (Gastropoda, Valvatidae), its systematic position and species content. Vestnik zoologii, 1. Pp. 9-14. (In Russian)

Starobogatov Ya. I., 1970. Molluscan fauna and zoogeographical divisions of the continental waterbodies of the globe. Leningrad: Nauka, 372 p. (In Russian).

Welter-Schultes F.W. 2012. European non-marine molluscs, a guide for species identification. Göttingen: Planet Poster Editions, $679 \mathrm{p}$.

Manuscript received January 20, 2021;

revision accepted April 12, 2021.
Гожик П. Ф. Понтичні прісноводні молюски півАня України і Молдови. Київ, 2002. 96 с.

Гожик П. Ф., Ааценко А. Н. Пресноводные моммюски позАнего кайнозоя юга Восточной Европы. Часть 2. Семейства Sphaeriidae, Pisidiidae, Corbiculidae, Neritidae, Viviparidae, Valvatidae, Bithyniidae, Lithoglyphidae, Melanopsidae. Киев: ^огос, 2007. 256 c.

Hasprunar G. A nomenclator of extant and fossil taxa of the Valvatidae (Gastropoda, Ectobranchia). ZooKeys, 2014, 377 Pp. 1-172. https://doi.org/10.3897/zookeys.377.6032

Hawe A., Heß M., Haszprunar G. 3D reconstruction of the anatomy of the ovoviviparous (?) freshwater gastropod Borysthenia naticina (Menke, 1845) (Ectobranchia: Valvatidae). Journal of Molluscan Studies, 2013. 79 (3). Pp. 191-204. https://doi.org/10.1093/mollus/eyt018

Осипова А.С., Анистратенко В.В. Опыт применения статистических методов Аля изучения изменчивости раковинь молмюсков рода Borysthenia (Gastropoda: Valvatidae). Тези Аоповідей Конференції молодих АосліАників-зоологів, м. Київ, Інститут зоології НАН України, 14-15.11.2018 р. Київ, 2018. С. 16. (Зоологічний кур'єр, № 12.) http://mail.izan.kiev.ua/ rmd/KMDZ18-abstr.pdf

Осипова А.С., Анистратенко В.В., Анистратенко О.Ю. Изменчивость раковины брюхоногих моммюсков рода Borysthenia Lindholm, 1914 и использование промеров раковины Аля разграничения виАов: статистический поАХоА. Палеонтологические исследования Аоно-Анепровского прогиба: материалы международной научной конференции и XXXIX сессии Палеонтологического общества НАН Украины (Градижск, 14-16 мая 2019 г.). Киев, 2019. С. 88-89.

Ситникова Т.Я. Система байкальских эндемичных виАов рода Megalovalvata и некоторые вопросы системати ки семейства Valvatidae (Gastropoda Pectinibranchia). Зоологический журнал, 1983. 62 (1). Pp. 32-43.

Ситникова Т.Я., Старобогатов Я.И., Черногоренко Е. В. Род Borysthenia (Gastropoda, Valvatidae), его систематическое положение и видовой состав. Вестник зоологии, 1986, 1. C. 9-14.

Старобогатов Я.И. Фауна моммюсков и зоогеографическое районирование континентальных водоемов Земного шара. ^енинград: Наука, 1970. 372 с.

Welter-Schultes F. W. European non-marine molluscs, a guide for species identification. Göttingen: Planet Poster Editions, 2012. 679 p.

${ }^{1}$ Національний університет "Києво-Могилянська академія", Київ, Україна

${ }^{2}$ Інститут геологічних наук НАН України, Київ, Україна

3нститут зоології ім. І. І. Шмальгаузена НАН України, Київ, Україна 


\title{
ИЗМЕНЧИВОСТЬ РАКОВИНЫ БРЮХОНОГИХ МОМЮСКОВ \\ POAA BORYSTHENIA LINDHOLM, 1914: TЕСТИРОВАНИЕ СТАТИСТИЧЕСКОГО ПОАХОАА В ПОИСКАХ ПРИЗНАКОВ АМЯ РАЗГРАНИЧЕНИЯ СОВРЕМЕННЫХ И ИСКОПАЕМЫХ ВИАОВ
}

\author{
А. С. Осипова, О.Ю. Анистратенко, В. В. Анистратенко
}

Род брюхоногих момююсков Borysthenia Lindholm, 1914 включает множество видов по всей Европе, Азии, Северной Африке и Северной Америке, но определение границ виАов, основанное, главным образом, на морфологии раковины (единственно возможное Аля ископаемых находок), часто является спорным. Нами использованы статистические методы обработки промеров раковины гастропод рода Borysthenia Аля проверки, являются ли параметры раковины надежным признаком разграничения современных и ископаемых видов. Наш анализ основан на количественном изучении более 100 экземпляров Borysthenia, как современных, так и ископаемых. САелан вывод о том, что размерные характеристики раковины пригодны Аля Аифференциации как современных, так и ископаемых (по крайней мере, понтического возраста) видов путем статистической обработки количественных Аанных. Изучение типового материала позволило уточнить таксономический статус B. jalpuchense Gozhik, 2002 и B. vinogradovkaense Gozhik, 2002, описанных из среАне-понтических отложений Украины. ПреАлагается считать эти таксоны Авумя отАельными, хотя и близкородственными вымершими виАами. Стратиграфический диапазон B. jalpuchense расширен до нижнего понта. Все современные особи Borysthenia отнесены к B. menkeana (Jelski, 1863), поскольку они точно соответствуют мектотипу этого вида.

Ключевые слова: Valvatidae, Borysthenia, ископаемые и современные вилы, морфология раковины, таксономия, южная Украина. 